\title{
ACCOUNTABILITY DISCLOSURE OF SOEs: COMPARING HYBRID AND PRIVATE EUROPEAN NEWS AGENCIES
}

\section{Structured Abstract}

Purpose: This paper explores the financial and non-financial accountability disclosure patterns of State-Owned Enterprises (SOEs), as hybrid organizations.

Design and methodology: Adopting the hybridity concept and resorting to stakeholder theory, this paper works on a comparison between the accountability disclosure patterns of hybrid and private organizations operating in the same industry. European national News Agencies (NAs) are selected as units of analysis and an extensive web content analysis is performed on three categories of information.

Findings: SOEs are found to disclose a broader spectrum of information than private organizations, and differences between them have been found. Nevertheless, both financial and non-financial disclosures are underdeveloped in the two organizational types.

Research limitations/implications: This paper illustrates how hybridity explains SOEs' accountability disclosure patterns. Results could not be complemented through information on disclosure through alternative channels. Future studies are encouraged to perform simultaneous comparisons among hybrid, public and private organizations, as well as considering industry specifics.

Practical implications: As web accountability disclosure helps to address the demands of distant stakeholders, efforts are needed to enhance SOEs' web accountability disclosures, and not to undermine democratic accountability relationships.

Originality/value: This paper contributes to the ongoing debate on the accountability mechanisms and style of SOEs. Using a framework for hybrid organizations, it provides an understanding of how SOEs, as hybrid organizations, disclose information for accountability. In turn, this allows, and then promotes, the investigation of social phenomena by conceiving hybridity as a standalone institutional space.

Keywords: state-owned enterprises, hybrid organizations, accountability disclosures, stakeholders, news agencies. 


\section{ACCOUNTABILITY DISCLOSURE OF SOEs: COMPARING HYBRID AND PRIVATE EUROPEAN NEWS AGENCIES}

\section{Introduction}

State-Owned Enterprises (SOEs) and their activities have received increased attention around the world (Grossi, Papenfuß, \& Tremblay, 2015; Grossi, Piber, \& Sargiacomo, 2019; Grossi \& Thomasson, 2015). State-Owned Enterprises (SOEs) are corporate entities recognized by national law as enterprises, in which the state exercises majority ownership, and are affected by specific governmental supervision. SOEs are engaged in the provision of public services of general economic and social interest whose performance is of great importance for broad segments of the population (Grossi et al., 2015; Royo, Yetano, \& García-Lacalle, 2019; Tremblay, 2012). The world's 2,000 largest SOEs employ more than 6 million people, their operating revenues make up 19\% of international trade and their total sales represent $6 \%$ of the world's gross national income (Florio, Ferraris, \& Vandome, 2018). Their dimension, both in terms of assets and turnover, is big enough for them to compete with private firms on the global market (Kowalski, Büge, Sztajerowska, \& Egeland, 2013).

The economic and social relevance of SOEs raises questions about which models, mechanisms, instruments and processes public authorities and SOEs could use to promote the effective, efficient, transparent and sustainable provision of public services (OECD, 2015; Xie and Redding, 2018). Considering that exposing processes and performance to public scrutiny provides strong incentives for good management, attentions is growingly paid to SOEs' outward accountability disclosures regarding financial and non-financial information (Luke, 2010; Mulgan, 1997; Royo et al., 2019). Accountability is not only connected to compliance and responsiveness (being held to and taking account of) but also concerns transparency (giving accounts). Transparency and information disclosures bring about accountability (Shaoul, Stafford, \& Stapleton, 2012). Thus, information - which must be gathered, processed and communicated - becomes a key factor in any accountability arrangement (Mulgan, 2000). Acknowledging that transparency and disclosure of information is a mechanism of accountability that delivers reasons for decision-making (Ball, 2009), this paper focuses on the information phase of the accountability process, with particular regard to the outward (also named horizontal and downwards) accountability process (Royo et al., 2019). ${ }^{1}$

In the attempt to understand how mechanisms, instruments and processes are used by SOEs, scholars of many disciplines are increasingly stressing the need to address the duality of their mission, and to avoid placing them within the defined borders of the traditional "public" and "private" worlds (Bruton, Peng, Ahlstrom, Stan, \& Xu, 2015). SOEs are exposed to relevant monitoring and accountability pressures, and face governance issues different from those of private organizations and public institutions (Grossi et al., 2015, 2019; Grossi \& Thomasson, 2015). This explains why the hybridity notion, "an impure existence between pure types" (Johansson \& Vakkuri, 2018, p.1), is increasingly resorted in order to study SOEs (Ebrahim, Battilana, \& Mair, 2014; Grossi,

\footnotetext{
${ }^{1}$ Outward accountability refers to the direct accountability to individuals (including customers), community groups, and the public at large. It is distinguished from both inward and upward accountabilities, respectively referring to a personal type of accountability and to accountability for political and managerial purposes (see Mulgan, 1997; Luke, 2010). Though all types of accountability are relevant for SOEs (Grossi and Thomasson, 2015), this paper focuses on outward accountability as it is transparency related rather than managerially or politically related.
} 
Reichard, Thomasson, \& Vakkuri, 2017; Shaoul et al., 2012). As for outward accountability, the mixing of politics and markets within the same organizational form can create difficulties for an external observer who tries to apply existing principles of accountability to hybrid activities (Johansson \& Vakkuri, 2018). Hybridity creates accountability structures that are inherently ambiguous, as they combine the responsibility towards shareholders of a typical stock held company - which is more clearly defined with the responsibility to electoral constituencies in political systems (Almquist, Grossi, van Helden, \& Reichard, 2013; Koppell, 2005). Independently of the specific form they can take, hybrid organizations share the following accountability problems: who is accountable for what and to whom? (Agostino \& Arnaboldi, 2017; Grossi \& Thomasson, 2015) and what levels of accountability can citizens expect from their collectively owned organizations? (Roper \& Barker, 2011).

Understanding how hybrid organizations ensure transparency and accountability has been scarcely investigated, though it would be relevant to both policymakers and practitioners for regulatory purposes (Chris Skelcher \& Smith, 2017). This raises an urgent call to study how SOEs, as hybrid organizations (Christensen, 2017; Florio \& Fecher, 2011), deal with accountability demands of external stakeholders (Olsen, Solstad, \& Torsteinsen, 2017). Targeting this literature gap, this paper uses the stakeholder theory lens to explore the outward accountability patterns of SOEs regarding the disclosure of financial and non-financial information. Assuming that accountability relationships search for legitimacy and vary among different type of stakeholders, industries and organizations within the same industry, the novelty of this paper lies in working on the differences between SOEs (hybrids) and private organizations (pure type) operating in the same industry.

This considered, the empirical setting is offered by European News Agencies (NAs) as the central hub in the news industry. On the one hand, focusing on NAs enables to conduct an empirical analysis on an industry that provides a relevant public good, where both hybrid and private organizational forms coexist under increasing accountability pressures (Appelgren \& Salaverría, 2018; Karlsson, 2010). On the other hand, comparing European NAs seems particularly suitable for the purpose of this study, as they belong to democratic societies, are bound by the competition rules of the European Union, and face similar challenges (Juntunen \& Nieminen, 2019). The empirical analysis is accomplished through an extensive web content analysis of European NAs on three distinct categories of information.

This paper addresses three gaps in the academic research. Firstly, it contributes to the ongoing debate on the financial and non-financial accountability disclosures of SOEs as a tool for legitimacy, analyzing how web disclosure patterns can help to the accountability of these organizations (Allini, Manes Rossi, \& Hussainey, 2016; Grossi et al., 2019; Shaoul et al., 2012). Secondly, this paper welcomes the growing call to study hybridity as a standing alone institutional space - rather than as a residual area among pure types (Bruton et al., 2015)- resorting to Johansson and Vakkuri (2018) as a theoretical framework adapted to SOEs organizational particularities. In doing so, a third contribution consists in addressing the conceptual ambiguities related to the adaptation of accountability in hybrid contexts. From a practical point of view, this paper sheds light on which stakeholders are targeted by SOEs web disclosures, thus stimulating a reflection on how disclosure regulations could enhance the outward accountability towards distant stakeholders.

The remainder of the paper proceeds as follows. Next section presents the theoretical notions that enable to develop propositions on SOEs' accountability disclosure patterns. Section three describes the research design, while section four presents the findings. Finally, sections five and the six respectively discuss results and draw conclusions. 


\section{Theoretical framework}

\subsection{SOEs organizational features: hybrid vs. private type}

SOEs are considered hybrid organizations because they face challenges and risks that are similar to private organizations, while they differ due to their crucial societal role, their business models incorporate both profitability and sustainability objectives, which may conflict with each other, and they can combine public and private ownership (Alberti \& Garrido, 2017; Argento, Grossi, Persson, \& Vingren, 2019; Bruton et al., 2015; Vakkuri \& Johanson, 2018). In order to frame SOEs as hybrid organizations, this paper refers to Johansson and Vakkuri (2018). The authors define hybrid organizations as organizational forms featured by: multiplicity of funding arrangements (1), mixed ownership (2), goal incongruence and competing institutional logics (3) and public and private forms of financial and social control (4). By exploring these features, the remainder of the section compares - as this paper does - SOEs, as a specific type of hybrid organizations, with private organizations.

Funding and ownership are two sides of the same coin, as the funding sources vary according to the entity's ownership. Private organizations are funded by their private owners (shareholders) and there is a clear link between ownership and funding sources (Hodge \& Greve, 2007) and, hence to whom accounts must be rendered in the first place. By contrast, hybrid organizations are featured by mixed ownership. SOEs, as defined in this paper, are wholly or majority owned by governmental entities on behalf of the general public - that pay taxes and elect the government - as well as on behalf of other possible minority interest groups (Grossi \& Thomasson, 2015). As such, SOEs receive public funds from governments, through budgetary assignments, and have close (government) and distant (citizen) owners. This structure creates additional layers when rendering accounts (Pina, Torres, \& Yetano, 2009).

SOEs' hybridity also refers to the incongruence of the goals they pursue and the competing institutional logics they face (Argento, Culasso, \& Truant, 2016; Olsen et al., 2017; Thornton, Ocasio, \& Lounsbury, 2012). While private organizations refer to a coherent set of business or market logics, SOEs should combine the latter with the logic of societal effectiveness, as a result of needing to exist as market-based public organizations that have to meet societal expectations (Christensen, 2017; Johansson \& Vakkuri, 2018). Private organizations have the foremost objective to create financial value for their owners. Even though non-financial objectives - such as the societal respect - may be considered, directors of private organizations are generally expected, under for-profit law, to maximize owners' wealth (Aguilera \& Jackson, 2010). SOEs should be able to create financial value for their owners, or at least be financially sustainable, and to have social impact on citizens and society at large. Public value creation is a broader category of value generation than profit seeking, as it encompasses both the satisfaction of citizens' needs and the efficient use of public resources, in a way to safeguard the ability to provide public value to future generations (Moore, 1995).

In most competitive contexts, it is reasonable to argue that maximizing profit is consistent with a positive social value (Vining \& Weimer, 2017). However, as hybrids are often created owing to market failures and are characterized by the presence of citizens as distant owners, public value should have a prominent position (Greiling, Traxler, \& Stötzer, 2015). SOEs have a social responsibility that plays a leading role in their concerns (Garde Sánchez, Rodríguez Bolívar, \& López Hernández, 2017). Therefore, they have to address those concerns by 'doing well by doing good,' where 'good' refers to legitimate social aims, and 'well' is understood as being efficient and effective (Ebrahim et al., 2014; Pache \& Santos, 2013). 
Finally, regarding control, it should be noticed that it is difficult to distinguish between private and public forms of control. In modern control systems, private entities and SOEs are simultaneously monitored by internal and external controls by a variety of public and private actors, thus resulting in mixed forms of financial and social control (Vakkuri \& Johanson, 2018). Forms such as professional, technical and ethical regulation, as well as customer-driven controls may apply to a given service delivery system, regardless of the types of organizations (Kickert, 2001; Vakkuri \& Meklin, 2006). Nevertheless, due to the presence of the government as owner, SOEs are under additional controls. The price SOEs pay for more managerial freedom, than public institutions, is to accept greater performance control (Olsen et al., 2017). Thus, an effective reporting regime requires SOEs to abide by the same reporting, control, and audit frameworks as other significant corporate or public interest entities and to disclose both financial and non-financial information (Alexius \& Cisneros Örnberg, 2015; Ntim, Soobaroyen, \& Broad, 2017; OECD, 2015). Public monitoring should not assume that social value can be assessed uniquely by profitability, as it can be in undistorted, well-functioning markets (Vining \& Weimer, 2017). Moreover, the governmental oversight of SOEs places relevance on control dimensions such as the execution of budgetary assignments and the environmental and social impact of their activities (Gallo \& Christensen, 2011). Furthermore, this type of control, is most of the time, exercised by the appointment of state representatives at the board of directors, contributing to increase the multiplicity of tight and loose forms of control in SOEs (Koppell, 2005). This creates a more demanding accountability for SOEs that has a different structure than the one of private organizations. Combining financial and nonfinancial reporting seems to be key to satisfy state and market logics, and the same for the different SOEs' stakeholders.

Stemming from the characteristics of SOEs discussed above, to explore the outward disclosure patterns of SOEs, this paper resorts to theoretical streams that focus on the legitimacy concept. Indeed, the outward accountability disclosure problem relates to the legitimization of organizations practices towards a society that expects results (Andrades Peña \& Larrán Jorge, 2019; Deegan, 2006). In particular, this paper focuses on the stakeholder theory, as analyzing how SOEs legitimate their activities should not neglect their need to acquire support and funds for their existence from multiple sources with different objectives and which subjected them to different control processes (Farneti, Casonato, Montecalvo, \& de Villiers, 2019).

\subsection{Accountability disclosure and critical stakeholders}

Theoretical streams based on the concept of legitimacy posit that organizational strategies - including accountability disclosure strategies - result from the perception that organizational members have about what the society expects the organization ought to do (Buchholz \& Rosenthal, 2005; Deegan, 2002; Garde Sánchez et al., 2017). Through outward accountability, organizations are expected to legitimate their actions to the public on their performance (Bovens, Schillemans, \& Hart, 2008). However, as sources of legitimacy vary depending on ownership, goals, logics and controls responses to legitimacy claims are also expected to differ between SOEs and private organizations. Hybrid structures, as those of SOEs, represent the unintended consequences of transforming "public hierarchies" into "markets" and require constant legitimization of their existence (Vakkuri \& Johanson, 2018).

The stakeholder theory (SHT) identifies stakeholders as particular groups of subjects with specific expectations about the organization's conduct, who will negotiate different 
social contracts with a given organization (Deegan, 2002) ${ }^{2}$. A fundamental thesis of stakeholder-based arguments is that organizations should be managed in the interests of all their constituents. The stakeholder theory (Freeman, 1984), provides a theoretical explanation for accountability relationships where in addition to or instead of shareholders, other stakeholders influence managerial decisions (Ellwood \& Garcia-Lacalle, 2015). Stakeholders have something to gain or to lose as a result of the corporation's activities (Clarkson, 1995, 1998). The SHT scholars' concerns about the interactions between organizations and their stakeholders have given rise to the managerial SHT (Freeman, 1984; Mitchell, Wood, \& Agle, 1997). This perspective shows that there are not only different stakeholders, but also differences on how organizations manage their different and frequently contrasting claims (Gibson, 2000; Mitchell et al., 1997).

Considering that organizations' survival requires to identify and meet the stakeholders' claims (Donaldson \& Preston, 1995; Freeman, 1984), those claims can be perceived as constraints on the organizational strategies (Freeman, 2004). In the discussion on the dynamics of stakeholders' influence, Freeman (1984) stresses that as the degree of achievement of organizational goals largely depends on management ability to meet stakeholders' demands, prioritizing among different claims is fundamental. To this regard, Clarkson (1995) distinguishes between primary and secondary stakeholders and, in a similar vein, Ulmann (1985) refers to the "powerful stakeholders". These authors suggest that priority is given to the stakeholders that provide vital support to the organizations. By contrast, lower attention is paid to those stakeholders that are not critical for organizations' survival. Accordingly, the importance that an organization gives to a specific group of stakeholders depends on the resources the group provides (Deegan, 2002; Wallace, 1995). Considering that accountability involves an obligation of the actor to explain and justify conduct which may well have consequences (Bovens, 2006), the stakeholders' power and the attention they capture from the organization can be justified by the stakeholders' capacity to generate consequences, not only by providing or not providing resources but also using other types of punishments.

Following the SHT, outward accountability disclosure of financial and non-financial information constitutes a dialogue between the organization and its stakeholders, through which the former provide information on its activities to legitimize its behavior (C. A. Adams \& Larrinaga, 2007). In this dialogue, it is expected that the disclosure patterns will firstly address the accountability needs of those groups of stakeholders that control key resources for survival (Lu \& Abeysekera, 2014; Thijssens, Bollen, \& Hassink, 2015). Drawing from the discussed differences between hybrid and private types of organizations and building on the stakeholder theory insights, Figure 1 depicts the main theoretical implications on their accountability disclosure patterns, highlighting the relationships arising and the source through which outward accountability can be rendered to each accountability demander.

\section{[INSERT FIGURE 1 HERE]}

\footnotetext{
${ }^{2}$ This conceptualization of organizations is in some respects overlapping the legitimacy theory (LT). The LT postulates that organizations are constrained to act in compliance with the terms of their "social contract". This social contract represents the multitude of explicit and implicit expectations that society has about the organization (Donaldson, 1982). By contrast, the SHT refers to particular groups within the society, the stakeholders. It focuses on how an organization interacts with these stakeholders, whereas the LT concentrates on interactions with "society" as a whole. Thus, even though both theories prove to fit well to study accountability disclosure patterns, the SHT enables to stress, and focus on, the multiplicity of stakeholders and stakeholders' claims that characterize hybrid organizations.
} 
As addressing divergent stakeholders' expectations may produce different accounts targeted for each relevant stakeholders group (Cerbone \& Maroun, 2020), Figure 1 reflects that besides financial and non-financial information having become key and complementary, especially for managerial purposes, when it comes to outward accountability levels of financial and non-financial disclosure may differ (Dumay \& Hossain, 2019; Garde Sánchez et al., 2017; Steurer \& Hametner, 2013).

In private organizations, the sole presence of private investors as owners and funders makes the emphasis on the financial performance for private gains an important anchor for accountability (Argento et al., 2019). Nonetheless, private organizations are increasingly called to demonstrate the link between the social, environmental and financial dimensions of their activities, in order to gain societal respect and meet the accountability demands of stakeholders (Bernardi \& Stark, 2018; Branco \& Rodrigues, 2008; Deegan, 2017). On the one hand, the disclosure of non-financial information is key to the creation of wealth to the owners (C. A. Adams, Potter, Singh, \& York, 2016; Rinaldi, Unerman, \& de Villiers, 2018), as it is perceived as a means to signal the organizations' ability to cope with environmental and social contingencies that are likely to impact on their business, thus affecting their capability to produce financial value in the future (C. A. Adams et al., 2016; Churet \& Eccles, 2014). On the other hand, through non-financial disclosures, private organizations hope to achieve and maintain good relationships with their own stakeholders, acquire a strong competitive advantage presenting a socially responsible image and positively influencing their own reputation (Ferguson, Lam, \& Lee, 2002; Garde Sánchez et al., 2017). Despite the growing importance given to non-financial information, its disclosure is highly related with the visibility of the organization (Ferguson et al., 2002) and is frequently low when it is not required by law (Dumay \& Hossain, 2019). Considering the above, and that vital resources are provided by private investors, private organizations are expected to prioritize the disclosure of financial information to render accounts. Nonfinancial information receives less attention on account of this objective. Moreover, as nonfinancial information represents the main accountability source for distant stakeholders (society), the pressure perceived to satisfy these stakeholders will also be low.

Hybrid organizations are placed under broader accountability foci due to their very nature (Ebrahim et al., 2014; Mair, Mayer, \& Lutz, 2015). SOEs are crucially supported by a broader set of stakeholders working both as financiers and owners, including governments, private investors, and citizens. The multiplicity of stakeholders creates tensions between the institutional logics represented, each of them with a different performance expectation (Chris Skelcher \& Smith, 2017), creating a space for multiple accountability channels (Thynne, 2017). Governmental power over SOEs is more binding as they provide vital resources. They, and private investors (if any), have a stake in pursuing financial sustainability. Similarly, to the private organizations, both financial and non-financial information will be relevant to this accountability relationship. However, non-financial information will be considered as complementary and instrumental for such informative needs, so it will represent an additional source of accountability in this respect.

The creation of public value is the central concern among citizens. Non-financial disclosures represent the need for accountability for public value enhancement (Moore, 1995) and societal respect (Córdoba-Pachón, Garde-Sánchez, \& Rodríguez-Bolívar, 2014). Despite that, citizens can be considered distant stakeholders, as they delegate the exercise of their ownership rights to governmental entities and work as indirect financers by paying taxes (Grossi \& Thomasson, 2015; Shaoul et al., 2012) They have stronger ties over SOEs, than society over private entities. Consequently, it can be expected that hybrid organizations disclose a broader set of information to address their multiple accountability demands and 
because, as Garde Sánchez et al (2017) argued, they are more exposed to the public scrutiny. However, it could be also expected that they will prioritize the disclosure of financial information in order to dialogue with and legitimize their activities to those stakeholders that provide vital resources. Thus, two propositions can be formulated as follows:

Proposition 1. Organizations (hybrid and private ones) give prominence to the financial information as a result of stakeholder prioritization.

Proposition 2. Hybrid organizations disclose a broader range of information as compared to private organizations.

\section{Research design}

\subsection{The empirical setting}

For the purpose of this paper, the empirical setting is provided by European NAs. NAs are undertakings that, regardless of the legal form, gather news and news material that express complete and impartial present facts, with the purpose to distribute it to news enterprises or exceptionally to private individuals - within the business practices (UNESCO, 1953). Hence, their mission is to provide a 'service of general interest', an important public service function dealing with a commodity that is in essence a public good (Karlsson, 2010). NAs have been selected as organizations providing a public relevant good, operating in an industry where both hybrid and private organizational forms can be found. Additionally, the European focus enables to explore the disclosure patterns of organizations that belong to democratic societies, are bound by the competition rules of the European Union, and face similar challenges (Juntunen \& Nieminen, 2019). Thus, the empirical setting is represented by 25 news agencies, which are those belonging to the European Alliance of News Agencies (EANA) that are also part of the EU $(28)^{3}$ plus Norway ${ }^{4}$. While the European Union (28) provides a common regulatory framework, the EANA membership - as an additional characteristic - implies that those agencies share some basics of the business that is under study $^{5}$. Table 1 shows the NAs that fulfill both criteria, distinguishing them in private (11 units) and hybrid organizations (14 units), according to the ownership. In the remainder of the paper, NAs are referred to with the name of the country of origin.

\section{[INSERT TABLE 1 HERE]}

\subsection{Data and methods}

Aiming at exploring the accountability disclosure of the sampled NAs, a web content analysis has been carried out ${ }^{6}$. Outward accountability, which depends upon the free flow

\footnotetext{
${ }^{3}$ Austria (1995); Belgium (1958); Bulgaria (2007); Croatia (2013); Cyprus (2004); Czech Republic (2004); Denmark (1973); Estonia (2004); Finland (1995); France (1958); Germany (1958); Greece (1981); Hungary (2004); Ireland (1973); Italy (1958); Latvia (2004); Lithuania (2004); Luxembourg (1958); Malta (2004); Netherlands (1958); Poland (2004); Portugal (1986); Romania (2007); Slovakia (2004); Slovenia (2004); Spain (1986); Sweden (1995); United Kingdom (1973-2020).

${ }^{4}$ Norway was included to have a greater picture of the Scandinavian countries.

5 The news agency business constitutes the very basics of news gathering and distribution. It is a business that needs a healthy environment abounding in freedom of the press, fair competition and simple and basic rules to operate. The members of the EANA are engaged in the promotion and the preservation of this environment (http://www.newsalliance.org/).

${ }^{6}$ A questionnaire was supposed to complement the lack of information emerging from the web content analysis Since some of the sought pieces of information were not available on the websites of the sampled agencies during the period of analysis, a questionnaire was sent
} 
of appropriate information (Mulgan, 2000) should be exercised in an open forum where organizations and managers make information available to the stakeholders for its scrutiny (Allini et al., 2016; Royo et al., 2019). As a result, ICTs and in particular web pages have become a crucial element to evaluate transparency and legal and voluntary disclosures, both in public and private sectors (Gandía, Marrahí, \& Huguet, 2016; Pina, Torres, \& Royo, 2010). Thus, e-disclosure or web disclosure have become a key element of outward accountability (Allini et al., 2016; Brusca, Cohen, Manes-Rossi, \& Nicolò, 2020; Royo et al., 2019).

A comprehensive website content analysis was carried out between mid-December 2017 and mid-January 2018. To ensure the quality of the data collected, the following actions were accomplished. Before the data collection, the authors separately analyzed 5 of the websites to check for consistency in the application of the coding criteria. Virtually no scoring differences were found, although some additional clarifications were introduced. During the analysis, the authors met several times to solve possible doubts. Adapting from Royo, Yetano and García-Lacalle (Royo et al., 2019), each website was analyzed for 40 items, divided into 3 categories (see Table 2). Scores of 0 and 1 have been respectively assigned to each NA for each item of information, considering whether it was disclosed or not on their websites. This has allowed to obtain the average score of disclosure in each of the three categories of information and for each type of organization ${ }^{7}$.

For selecting the items - and thus the related information categories - it was considered that the quality, range and format of information clearly influences the enforcement of accountability relationships. At the same time, the range and format of disclosure depends on the type of accountability being discharged, the formal accountability requirements, as well as the accountability main focus (Greiling \& Spraul, 2010). Therefore, it was established to focus on three information categories able to reflect the different accountability demands discussed in the previous section. Specifically, items are grouped in three categories: one on financial information, two regarding non-financial information, and a third one referred to the quality of the website.

The items belonging to the Financial information category regard information on organizations' financial position, allocation and use of funds. These are items that enable organizations to be held accountable for their financial performance and are usually required by law for all types of organizations. Those that have a public sector component (such as the budget or public procurement) are only evaluated for SOEs.

Non-financial information, which allows organizations to be held accountable for public value enhancement (if applicable) and the achievement of societal respect, is detected through items connected to the social, environmental and governance dimensions of their activities (C. A. Adams \& Larrinaga, 2007; S. Adams \& Simnett, 2011; O’Dwyer, Unerman, \& Bradley, 2005). Consequently, the presence of non-financial information on websites was analyzed considering two types of information. Firstly, Objectives, policies and strategies, including the analysis of the organizational mission and objectives, statutes, organizational chart, plans of annual objectives and related indicators, codes of conduct, CSR codes and reports, as well as documents specifying the fraud prevention policy and the risk management policy. Secondly, the Corporate governance information includes specific details on organizations' ownership structure, governing boards and top management composition and operation.

to their CFOs or - in the impossibility to directly contact them - to administrative offices and top managers, in order to assess whether they prepare and disclose the optional documents and reports that should contain the sought information, and, as for the documents that are not optional (such as statutes, financial statements, etc.) whether they are available on demand or on the website. Only three agencies answered the questionnaire even though it was sent three times (May, June and July 2018) and personalized for each agency. Thus, the results of the questionnaires have not been considered.

7 The results are descriptive. The authors carried out several statistical analyses, such as mean comparisons through Mann-Whitney, but given the low disclosure non-significance was found. Thus, these analyses have not been included. 
Finally, it is considered that for a website to be informative there are certain qualitative characteristics (of information disclosure) that are required. Thus, this category assesses the soundness in e-disclosure practices and covers items addressing the following aspects (Gandía et al., 2016; Pina et al., 2010): accessibility to the information, comparability, ease of management of the information, FAQs, and the possibility of establishing a dialogue between the organizations and interested stakeholders (interactivity).

\section{Findings}

The web content analysis results are presented for the whole sample, as well as comparing hybrid and private organizations. Table 2 shows the average disclosure for each of the three categories of information ${ }^{8}$. Scores resulting from the analysis of the whole sample indicate a poor level of disclosure in all the categories of information, with an average web disclosure that is around one third of the items analyzed. The category with greater disclosures globally is qualitative characteristics of the information $(64.94 \%)$, whereas financial information emerges as the least disclosed (20.41\%).

\section{[INSERT TABLE 2 HERE]}

Looking at the organizational typology, the hybrids' group has the highest level of disclosure, its NAs providing almost $35 \%$ of the information compared to $26.2 \%$ disclosed by their private counterparts. Reflecting the patterns observed on the whole sample, both hybrid and private NAs show the highest level of disclosure in the category regarding the Qualitative characteristics of information (See Table 2). On the contrary, the category less disclosed by both hybrid and private NAs is the Objectives, Policies and Strategy as a type of non-financial information (respectively, $21.43 \%$ and $14.55 \%$ ). Hybrid and private NAs show different patterns with regard the financial/non-financial dichotomy. While financial information is found to score almost 9 points percentage more than the non-financial category in the hybrid group, privates report the same scores for disclosures of financial and overall non-financial information (18.18\%).

To gain further insights into the accountability disclosures for each category of information, Tables 3 reports the average percentage of each item investigated.

\section{[INSERT TABLE 3 HERE]}

Table 3 shows that the most disclosed items pertaining to the Financial Information category are information on public procurement (only for hybrids) and financial statements. Though financial statements are disclosed by $36.4 \%$ of private NAs, only half of these actually provide them signed by the administrators and include a management and audit report. On the contrary, financial information of hybrid NAs is more comprehensive, as all the items are disclosed systematically to a greater extent than in the private group. Additionally, only a scant minority presents information on the payment period to suppliers, and they are hybrids.

Table 3 reports findings concerning non-financial information disclosure. Among the Objectives, policies, and strategies items, higher scores are found in the "objectives" - with almost half of the sample (48\%) disclosing this item - followed by the organizational chart, provided by $44 \%$ of the analyzed agencies. On the contrary, the least disclosed are those items referring to the performance measures and organizational policies, such as fraud

\footnotetext{
${ }^{8}$ The disclosure by NAs is available on request from the authors.
} 
prevention, remuneration, risk management, selection of board's members, and CSR. Analyzing the organizational typology, while hybrid NAs give similar importance to the organizational chart, objectives, and articles of association, private organizations are found to disregard the latter, with only $9 \%$ of them disclosing that item. As for the Corporate governance items, it can be appreciated that both the ownership structure and the composition of the top positions (directors and managers) are disclosed by at least half of the sampled NAs (respectively scoring $60 \%$ and 68\%). Nevertheless, when it comes to more specific information, a scant NAs' commitment emerges, reaching the lowest average score in the annual corporate report, which is disclosed only by $4 \%$ of the NAs, all of which are hybrids. Furthermore, information on the remuneration is not disclosed at all. Even though hybrid NAs are found to generally disclose more items of this informational subcategory than their private counterparts, the latter score higher for specifics related to the Board of Directors (BoD) composition, the top managers' status, as well as to the committees settled within the BoD.

As stated above, the information about the Qualitative characteristics scores the highest (see Table 3), both in the total sample and for both groups. Focusing on the single items composing this informational category, it emerges that the accessibility of information - as a dimension of its quality - is a concern of the NAs, as most of them include an internal search engine (84\%), a website map (64\%), and do not have broken-links (76\%). Except for the presence of hyperlinks and links to social networks pages on the website, hybrid NAs constantly disclose more than their private counterparts.

\section{Discussion}

Findings of this paper highlight peculiarities of hybrid organizations' outward accountability patterns vis à vis their private counterparts, regarding financial and nonfinancial information. Despite the fact, the disclosure of information by the investigated NAs shows a very low level of development, only the Qualitative characteristics scores are close to $50 \%$, certain differences across sectors can be outlined.

Resorting to the critical stakeholder notion (Clarkson, 1995; Ullmann, 1985) and acknowledging the importance given to organizations' financial performance (Aguilera \& Jackson, 2010), it was assumed that both private and hybrid organizations were going to give prominence to financial information (Proposition 1), with the non-financial information receiving less attention as a source of outward accountability. Though webs are considered powerful tools by NAs for their own business (Appelgren \& Salaverría, 2018), this paper shows that the web is not a key tool to fulfill accountability needs of critical stakeholders in this industry. Owing to the fact financial information is disclosed to a greater extent than non-financial one, the low level of disclosure achieved does not allow confirming a prominence to this type of information, so Proposition 1 is not confirmed. Considering that financial information is part of the legal control processes applied to corporations - e.g., preparation of financial statements is mandatory within the EU - results show that those stakeholders that want to supervise financial information have to use alternative channels, such as the distribution of financial reports to shareholders or their availability at the Chamber of Commerce. This implies that, for both hybrid and private organizations analyzed, the outward accountability disclosure to critical stakeholders have to take place ex-web. Moreover, the low presence of non-financial information confirms the low level of penetration of the web as a space where additional sources of accountability to critical stakeholders could be rendered. This undermines the role of non-financial 
information as an additional source of outward accountability for critical stakeholders of both hybrid and private organizations.

Results confirm the importance of distinguishing hybrids and the expectation that hybrid organizations - given their mix of funding sources and goals (Johansson \& Vakkuri, 2018) and the presence of distant stakeholders with stronger ties (the citizens)- were going to provide a broader spectrum of information (Proposition 2). In fact, this proposition is confirmed for all categories of information. Hybrid organizations are found to disclose higher amounts of financial and non-financial information on their websites. This suggests that web accountability disclosure, as a tool for outward accountability to critical and distant stakeholders becomes more important for hybrids than for private organizations. A close analysis to the financial information points out the existence of differences between hybrids and public ones, as the former hardly disclose budgetary information, which it is usually the most disclosed by public organizations (Pina et al., 2009). The differences between hybrids and public organizations should be explored by future studies, as suggested below.

Even though hybrids score better for all categories of information, results on the web disclosures within each category also reveal, for both types of organizations, a greater focus on the information that is easiest to prepare or that is already available (Behnam \& MacLean, 2011; Pina et al., 2009; Waddock, Gilbert, \& Rasche, 2011). This formal approach to web accountability disclosure is even evident for the category that scores the highest for all NAs -the Qualitative characteristics-. The poorest results are found among the information that requires a greater effort. Similarly, organizations provide generic nonfinancial information and avoid detailed reporting which would link economic, environmental and social performance explicitly (Cerbone \& Maroun, 2020). This indicates that, though some non-financial information is disclosed on the web, its low level of penetration does not allow strengthening the assessment of organizations' capability to generate financial value in the future (C. A. Adams et al., 2016; Churet \& Eccles, 2014), nor the creation of public value. These results confirm the expectations that despite nonfinancial information is key for managerial and accountability purposes, it is not deployed as a source of outward accountability to either critical or distant stakeholders. Greater disclosure through non-financial information usually reflects organizational 'good' social, economic and environmental conduct of the company that can then influence and enhance external perceptions (Garde Sánchez et al., 2017). For NAs, both SOEs and private, these external perceptions seem not to be a priority.This may be explained by the absence of a mandatory framework for non-financial disclosure in the empirical context chosen, as well as by a longer tradition and familiarity with financial disclosures (Dumay \& Hossain, 2019; Steurer \& Hametner, 2013).

Considering that critical stakeholders' demands for accountability can be primarily addressed ex-web, the low level of non-financial disclosure on the webs of the analysed NAs raises concerns over the need of enforcement of accountability relationships with distant stakeholders. Indeed, results from the analysed NAs imply that citizens' accountability needs - as distant owners of SOEs- suffer of a poor level of satisfaction. In turn, this confirms that the SOEs' inherent goal ambiguity (Christensen, 2017; Johansson \& Vakkuri, 2018), is likely to be solved through public goals displacement (Vining \& Weimer, 2017), whereby the public value creation and the accountability disclosure to that regard lose prominence. Furthermore, it can be observed that the outward accountability disclosure patterns shown by the analyzed SOEs contrast with the reporting developments experienced by public sector organizations in the last decades, according to which downward accountability to citizens has been increasingly emphasized (Collier, 2005; Pina et al., 2010). Coupled with the comparative analysis made in this paper, this confirms how 
hard it is to apply existing frameworks of accountability to hybrid organizations such as SOEs.

\section{[INSERT FIGURE 2 HERE]}

Recalling the representation of the theoretical outward accountability disclosure patterns provided in Figure 1, these findings have led to a refinement of the proposed framework (see Figure 2). Indeed, findings have permitted highlighting how the accountability disclosure to distant and critical stakeholders stems from on the channels through which accountability is rendered. The pattern of outward accountability disclosure of SOEs - as hybrid organizations - shows similarities and differences with the private organizations' one. To address accountability demands of their critical stakeholders regarding financial issues, the stakeholders will have to use ex-web resources. For nonfinancial disclosures, at this point, the web should be the main channel and it shows a low level of penetration. Hybrids perceive a greater pressure from their stakeholders and disclose a slightly higher amount of information, shown not only by the level of disclosure of budgetary information and the other items of financial information, but also by the depth and breadth of non-financial disclosure. However, the level of information provided seems not enough to account for the current and future capability to create financial and public value. Despite the fact the e-disclosure becoming a key tool for the outward accountability disclosure (Allini et al., 2016; Brusca et al., 2020; Royo et al., 2019), the web does not represent the space where critical and distant stakeholders can gather the primary sources that satisfy their accountability needs in this industry. Changes are needed in the sector to provide appropriate accountability levels through channels where the free flow of information can be guaranteed, as the web pages.

\section{Conclusions}

This paper has explored the outward accountability patterns of SOEs, showing the importance of adapting accountability expectations to each environment and to hybridity specifics. The web content analysis performed on European NAs has allowed us to propose both theoretical and practical contributions on SOEs' accountability disclosures of financial and non-financial information.

By combining the hybridity framework of Johansson and Vakkuri (2018) with notions from the management stakeholder theory, this paper has analyzed SOEs specifics regarding funding sources, ownership, organizational goals and control structures. By using the hybridity concept, SOEs are studied as an institutional space different from both the private and public ones (Ebrahim et al., 2014; Grossi et al., 2017) without forcing them into preexisting private or public accountability frameworks. As a result, it has been shown that, despite SOEs being corporate entities representing relevant players in the international markets (Florio et al., 2018), they do create accountability demands that are different from those of private organizations, resulting in different outward accountability disclosure patterns. It should be also highlighted that accountability is not high on the agenda of whatever type of NAs.

At the same time, the research path followed in this paper has underlined how the comparison with the "purer" types - that are better known - can help to explore the hybrid space - that is less known. Differently from previous studies that have focused on single sectors - either private or public - or by conducting country wide comparisons, this paper has investigated the outward accountability patterns of a type of organizations by relying on a cross-sector international comparison. 
From a theoretical point of view, the legitimization of operations and their survival are key concerns driving and shaping web accountability disclosure patterns of both SOEs and private organizations. Building on such conceptual premises, a second contribution is offered to the ongoing debate on SOEs' accountability disclosure (Grossi et al., 2019; Shaoul et al., 2012). Indeed, this paper provides an understanding of how SOEs' differentiate among critical and distant stakeholders and that the satisfaction of their related accountability needs stems on the channels through which accountability is rendered. SOEs' critical stakeholders - governments and private investors (if any) - can resort to channels other than websites to satisfy their financial accountability interests. Financial information, expected to represent the primary source of accountability demands of critical stakeholders and the additional one for distant stakeholders, does not have a strong predominance on organizational' websites. Non-financial accountability has the web as the main source, however web accountability disclosure is hardly used for addressing the main accountability demands of distant stakeholders. SOEs provide small pieces of information of everything but nothing in big detail. Distant stakeholders play a more relevant role for SOEs than for private organizations, but this is not enough to create a high web disclosure setting able to satisfy their accountability needs. Financial sustainability information requires an effort beyond the web to satisfy accountability demands. Public value is perceived as a distant demand, or at best as a secondary source, for critical accountability demanders, consequently web non-financial accountability disclosure does not represent a real endeavor for them. This draws us to the conclusion that the SOEs' peculiar multiplicity of accountability foci (Koppell, 2005) is dealt through stakeholder prioritization.

From a practical point of view, this paper contributes to considering SOEs' hybridity as crucial to understand how they interact within their environment. As long as hybrid organizations are framed separately from pure types, their peculiarities in the accountability disclosure patterns should be considered for regulatory improvements (Chirs Skelcher \& Smith, 2015). With regards to the provision of financial information, this paper highlights the need to ensure greater homogeneity in web accountability disclosures. For nonfinancial information disclosures, regulation should have a broader scope. This would not only enhance the role of e-disclosure as an additional accountability source for critical stakeholders, but it would also strengthen the accountability towards citizens - as distant stakeholders - with lower opportunities to obtain information via other channels. Within the complex and ambiguous accountability structures created by hybridity, citizens' accountability demands fulfil an essential democratic postulate (Ebrahim et al., 2014; Grossi \& Thomasson, 2015). Thus, a disclosure regulation tailored on hybrid organizations should be oriented to avoid seeing citizens as distant or uncritical stakeholders and should consider web accountability disclosure a key tool to reduce the distance.

As a limitation of the study, it should be highlighted that it was not possible to complement the analysis of web disclosure with an additional questionnaire oriented to identifying disclosures made by other channels and legal requirements of the information analyzed. Furthermore, the results represent an image in one moment of time, so that future studies may show a different evolution of accountability disclosures in this industry. Nevertheless, this exploratory paper is of value as a starting point to define the particularities of SOEs as hybrid organizations and their accountability disclosures pattern. Future studies could embark on a comparison among hybrid, private and public organizations, as could be the case of hospitals and universities. Moreover, adopting a deductive approach, future studies may also test the framework here provided in larger settings. Not least, building on the hybridity framework here provided, future studies are welcomed to investigate which factors may influence SOEs' disclosure patterns. The literature on organizations' disclosure provides insights on the relevance of some governance, financial and cultural variables that may have a stake in this respect. 
Particularly, in an increasing call for interdisciplinary perspectives, industry specifics may enrich the understanding of the accountability relationships - and demands - SOEs are deemed to address. 


\section{References}

Adams, C. A., \& Larrinaga, C. (2007). Engaging with organisations in pursuit of improved sustainability accounting and performance. Accounting, Auditing \& Accountability Journal, 20(3), 333-355.

Adams, C. A., Potter, B., Singh, P. J., \& York, J. (2016). Exploring the implications of integrated reporting for social investment (disclosures). British Accounting Review, 48(3), 283-296.

Adams, S., \& Simnett, R. (2011). Integrated Reporting: An Opportunity for Australia's Not-for-Profit Sector. Australian Accounting Review, 21(3), 292-301.

Agostino, D., \& Arnaboldi, M. (2017). Rational and ritualistic use of key performance indicators in hybrid organizations. Public Money and Management, 37(6), 409-416.

Aguilera, R. V., \& Jackson, G. (2010). Comparative and international corporate governance. Academy of Management Annals, 4(1), 485-556.

Alberti, F. G., \& Garrido, M. A. V. (2017). Can profit and sustainability goals co-exist? New business models for hybrid firms. Journal of Business Strategy, 38(1), 3-13.

Alexius, S., \& Cisneros Örnberg, J. (2015). Mission(s) impossible? Configuring values in the governance of state-owned enterprises. International Journal of Public Sector Management, 28(4-5), 286-306.

Allini, A., Manes Rossi, F., \& Hussainey, K. (2016). The board's role in risk disclosure: an exploratory study of Italian listed state-owned enterprises. Public Money and Management, 36(2), 113-120.

Almquist, R., Grossi, G., van Helden, G. J., \& Reichard, C. (2013). Public sector governance and accountability. Critical Perspectives on Accounting, 24(7-8), 479487.

Andrades Peña, J., \& Larrán Jorge, M. (2019). Examining the amount of mandatory nonfinancial information disclosed by Spanish state-owned enterprises and its potential influential variables. Meditari Accountancy Research, 27(4), 534-555.

Appelgren, E., \& Salaverría, R. (2018). The Promise of the Transparency Culture: A comparative study of access to public data in Spanish and Swedish newsrooms. Journalism Practice, 12(8), 986-996.

Argento, D., Culasso, F., \& Truant, E. (2016). Competing logics in the expansion of public service corporations. Utilities Policy, 40, 125-133.

Argento, D., Grossi, G., Persson, K., \& Vingren, T. (2019). Sustainability disclosures of hybrid organizations: Swedish state-owned enterprises. Meditari Accountancy Research, 27(4), 505-533.

Ball, C. (2009). What Is Transparency? Public Integrity, 11(4), 293-308.

Behnam, M., \& MacLean, T. L. (2011). Where Is the Accountability in International Accountability Standards?: A Decoupling Perspective. Business Ethics Quarterly, 21(1), 45-72.

Bernardi, C., \& Stark, A. W. (2018). Environmental, social and governance disclosure, integrated reporting, and the accuracy of analyst forecasts. British Accounting Review, 50(1), 16-31.

Bovens, M. (2006). Analysing and assessing public accountability. European Governance Papers (EUROGOV), (C-06-01), 1-37. Retrieved from http://www.connex-network.org/eurogov/pdf/egp-connex-C-06-01.pdf.

Bovens, M., Schillemans, T., \& Hart, P. T. (2008). Does public accountability work? An assessment tool. Public Administration, 86(1), 225-242.

Branco, M. C., \& Rodrigues, L. L. (2008). Factors influencing social responsibility disclosure by Portuguese companies. Journal of Business Ethics, 83(4), 685-701.

Brusca, I., Cohen, S., Manes-Rossi, F., \& Nicolò, G. (2020). Intellectual capital 
disclosure and academic rankings in European universities: Do they go hand in hand? Meditari Accountancy Research, 28(1), 51-71.

Bruton, G. D., Peng, M. W., Ahlstrom, D., Stan, C., \& Xu, K. (2015). State-owned Enterprises Around the WORLD as Hybrid Organizations. Academy of Management Perspectives, 29(1), 92-114.

Buchholz, R. A., \& Rosenthal, S. B. (2005). Toward a contemporary conceptual framework for stakeholder theory. Journal of Business Ethics, 58(1), 137-148.

Cerbone, D., \& Maroun, W. (2020). Materiality in an integrated reporting setting: Insights using an institutional logics framework. British Accounting Review.

Christensen, L. T. (2017). How hybridity has evolved in the governance of state-owned enterprises: evidence from Danish and Swedish passenger rail services from 1990 to 2015. Public Money and Management, 37(6), 401-408.

Churet, C., \& Eccles, R. G. (2014). Integrated Reporting, Quality of Management, and Financial Performance. Journal of Applied Corporate Finance, 26(1), 56-64.

Clarkson, M. B. E. (1995). A Stakeholder Framework for Analyzing and Evaluating Corporate Social Performance. Academy of Management Review, 20(1), 92-117.

Clarkson, M. B. E. (1998). The Corporation And Its Stakeholders: Classic and Contemporary Readings. Toronto: University of Toronto Press.

Collier, P. M. (2005). Governance and the quasi-public organization: A case study of social housing. Critical Perspectives on Accounting, 16(7), 929-949.

Córdoba-Pachón, J.-R., Garde-Sánchez, R., \& Rodríguez-Bolívar, M.-P. (2014). A Systemic View of Corporate Social Responsibility (CSR) in State-Owned Enterprises (SOEs). Knowledge and Process Management, 21(3), 206-219.

Deegan, C. (2002). Introduction: The legitimising effect of social and environmental disclosures - a theoretical foundation. In Accounting, Auditing \& Accountability Journal (Vol. 15).

Deegan, C. (2006). Legitimacy theory. In Z. Hoque (Ed.), Metodological issues in accounting research. Theories, methods and issues (pp. 161-182). London: Spiramus Press.

Deegan, C. (2017). Twenty five years of social and environmental accounting research within Critical Perspectives of Accounting: Hits, misses and ways forward. Critical Perspectives on Accounting, 43, 65-87.

Donaldson, T. (1982). Corporations and morality. Retrieved from https://books.google.es/books?hl=es\&lr=\&id=kjYKgOPspPkC\&oi=fnd\&pg=PP7\&d $\mathrm{q}=$ corporations + and + morality\&ots $=\mathrm{zHjz} \_$C11TT\&sig=loojvvdX-

0 GnEzsveh5vNMifoVw\# $\mathrm{v}=$ onepage $\& \mathrm{q}=$ corporations and morality $\& \mathrm{f}=$ false

Donaldson, T., \& Preston, L. E. (1995). the Stakeholder Theory of the Corporation: Concepts, Evidence, and Implications. Academy of Management Review, 20(1), 6591.

Dumay, J., \& Hossain, M. A. (2019). Sustainability Risk Disclosure Practices of Listed Companies in Australia. Australian Accounting Review, 29(2), 343-359.

Ebrahim, A., Battilana, J., \& Mair, J. (2014). The governance of social enterprises: Mission drift and accountability challenges in hybrid organizations. Research in Organizational Behavior, 34, 81-100.

Ellwood, S., \& Garcia-Lacalle, J. (2015). The Influence of Presence and Position of Women on the Boards of Directors: The Case of NHS Foundation Trusts. Journal of Business Ethics, 130(1), 69-84.

Farneti, F., Casonato, F., Montecalvo, M., \& de Villiers, C. (2019). The influence of integrated reporting and stakeholder information needs on the disclosure of social information in a state-owned enterprise. Meditari Accountancy Research, 27(4), $556-579$. 
Ferguson, M. J., Lam, K. C. K., \& Lee, G. M. (2002). Voluntary Disclosure by Stateowned Enterprises Listed on the Stock Exchange of Hong Kong. Journal of International Financial Management and Accounting, 13(2), 125-152.

Florio, M., \& Fecher, F. (2011). The Future of Public Enterprises: Contributions to a New Discourse. Annals of Public and Cooperative Economics, 82(4), 361-373.

Florio, M., Ferraris, M., \& Vandome, D. (2018). State-Owned Enterprises: Rationales for Mergers and Acquisitions (No. 2018/01).

Freeman, R. E. (1984). Strategic Management: A Stakeholder Approach. New York: Financial Times Prentice Hall.

Freeman, R. E. (2004). Stakeholder Theory of the Modern Corporation. In N. E. Bowie (Ed.), Ethical Theory and Business (pp. 56-65). Upper Saddle River: Prectice Hall.

Gallo, P. J., \& Christensen, L. J. (2011). Firm Size Matters: An Empirical Investigation of Organizational Size and Ownership on Sustainability-Related Behaviors. Business \& Society, 50(2), 315-349.

Gandía, J. L., Marrahí, L., \& Huguet, D. (2016). Digital transparency and Web 2.0 in Spanish city councils. Government Information Quarterly, 33(1), 28-39.

Garde Sánchez, R., Rodríguez Bolívar, M. P., \& López Hernández, A. M. (2017). Corporate and managerial characteristics as drivers of social responsibility disclosure by state-owned enterprises. Review of Managerial Science, 11(3), 633659.

Gibson, K. (2000). The Moral Basis of Stakeholder Theory. Journal of Business Ethics, Vol. 26, pp. 245-257.

Greiling, D., \& Spraul, K. (2010). Accountability and the Challenges of Information Disclosure. Public Administration Quarterly, Vol. 34, pp. 338-377.

Greiling, D., Traxler, A. A., \& Stötzer, S. (2015). Sustainability reporting in the Austrian, German and Swiss public sector. International Journal of Public Sector Management, 28(4-5), 404-428.

Grossi, G., Papenfuß, U., \& Tremblay, M.-S. (2015). Corporate governance and accountability of state-owned enterprises. International Journal of Public Sector Management, 28(4/5), 274-285.

Grossi, G., Piber, M., \& Sargiacomo, M. (2019). Accounting, Performance, Hybrid Organizations, Hybridity. 2018-2020.

Grossi, G., Reichard, C., Thomasson, A., \& Vakkuri, J. (2017). Editorial. Public Money and Management, 37(6), 379-386.

Grossi, G., \& Thomasson, A. (2015). Bridging the accountability gap in hybrid organizations: The case of Copenhagen Malmö Port. International Review of Administrative Sciences, 81(3), 604-620.

Hodge, G. A., \& Greve, C. (2007). Public-Private Partnerships: An International Performance Review. Public Administration Review, 67(3), 545-558.

Johansson, J. E., \& Vakkuri, J. (2018). Governing Hybrid Organizations. Exploring Diversity of Institutional Life. New York: Routledge.

Juntunen, L., \& Nieminen, H. (2019). The future of national news agencies in Europe case study 3: the changing relationship between news agencies and the state.

Karlsson, M. (2010). Rituals of transparency: Evaluating online news outlets' uses of transparency rituals in the United States, United Kingdom and Sweden. Journalism Studies, 11(4), 535-545.

Kickert, W. J. . (2001). Public management of hybrid organizations: governance of quasiautonomous executive agencies. International Public Management Journal, 4(2), 135-150. Retrieved from https://www.sciencedirect.com/science/article/pii/S1096749401000496

Koppell, J. G. S. (2005). Pathologies of accountability: ICANN and the challenge of 
“multiple accountabilities disorder." Public Administration Review, 65(1), 94-108.

Kowalski, P., Büge, M., Sztajerowska, M., \& Egeland, M. (2013). State-Owned

Enterprises. Trade Effects and Policy implications. OECD Trade Policy Papers, (147).

Lu, Y., \& Abeysekera, I. (2014). Stakeholders' power, corporate characteristics, and social and environmental disclosure: evidence from China. Journal of Cleaner Production, 64, 426-436.

Luke, B. (2010). Examining accountability dimensions in state-owned enterprises. Financial Accountability and Management, 26(May), 134-162.

Mair, J., Mayer, J., \& Lutz, E. (2015). Navigating Institutional Plurality: Organizational Governance in Hybrid Organizations. Organization Studies, 36(6), 713-739.

Mitchell, R. K., Wood, D. J., \& Agle, B. R. (1997). Toward a Theory of Stakeholder Identification and Salience : Defining the Principle of Who and What Really Counts. Academy of Management Review, 22(4), 853-886.

Moore, M. H. (1995). Creating Public Value. Strategic Management in Government. Harvard University Press.

Mulgan, R. (1997). The processes of public accountability. Australian Journal of Public Administration, 56(1), 25-36.

Mulgan, R. (2000). “Accountability”: An Ever-Expanding Concept? Public Administration, 78(3), 555-573.

Ntim, C. G., Soobaroyen, T., \& Broad, M. J. (2017). Governance structures, voluntary disclosures and public accountability: The case of UK higher education institutions. Accounting, Auditing and Accountability Journal, 30(1), 65-118.

O’Dwyer, B., Unerman, J., \& Bradley, J. (2005). Perceptions on the emergence and future development of corporate social disclosure in Ireland: Engaging the voices of non-governmental organisations. Accounting, Auditing and Accountability Journal, $18(1), 14-43$.

OECD. (2015). OECD Guidelines on Corporate Governance of State-Owned Enterprises, 2015 Edition.

Olsen, T. H., Solstad, E., \& Torsteinsen, H. (2017). The meaning of institutional logics for performance assessment in boards of municipal companies. Public Money and Management, 37(6), 393-400.

Pache, A.-C., \& Santos, F. (2013). Inside the Hybrid Organization: Selective Coupling as a Response to Competing Institutional Logics. Academy of Management Journal, 56(4), 972-1001.

Pina, V., Torres, L., \& Royo, S. (2010). Is e-government promoting convergence towards more accountable local governments? International Public Management Journal, 13(4), 350-380.

Pina, V., Torres, L., \& Yetano, A. (2009). Accrual accounting in EU local governments: One method, several approaches. European Accounting Review, 18(4).

Rinaldi, L., Unerman, J., \& de Villiers, C. (2018). Evaluating the integrated reporting journey: insights, gaps and agendas for future research. Accounting, Auditing \& Accountability Journal, 31(5), 1294-1318.

Roper, J., \& Barker, J. R. (2011). Forum introduction: State-owned enterprises, corporate social responsibility, and organizational communication. Management Communication Quarterly, 25(4), 690-692.

Royo, S., Yetano, A., \& García-Lacalle, J. (2019). Accountability Styles in State-Owned enterprises: The good, the bad, the ugly ... And the pretty. Revista de Contabilidad-Spanish Accounting Review, 22(2), 156-170.

Shaoul, J., Stafford, A., \& Stapleton, P. (2012). Accountability and corporate governance of public private partnerships. Critical Perspectives on Accounting, 23(3), 213-229. 
Skelcher, Chirs, \& Smith, S. R. (2015). Theorizing Hybridity: Institutional Logics, Complex Organizations, and Actor Identities: The Case of Nonprofits. Public Administration, 93(2), 433-448.

Skelcher, Chris, \& Smith, S. R. (2017). New development: Performance promises and pitfalls in hybrid organizations - five challenges for managers and researchers. Public Money and Management, 37(6), 425-430.

Steurer, R., \& Hametner, M. (2013). Objectives and Indicators in Sustainable Development Strategies: Similarities and Variances across Europe. Sustainable Development, 21(4), 224-241.

Thijssens, T., Bollen, L., \& Hassink, H. (2015). Secondary Stakeholder Influence on CSR Disclosure: An Application of Stakeholder Salience Theory. Journal of Business Ethics, 132(4), 873-891.

Thornton, P. H., Ocasio, W., \& Lounsbury, M. (2012). The Institutional Logics Perspective: A New Approach to Culture, Structure and Process. Oxford, UK: Oxford University Press.

Thynne, I. (2017). Debate: A mixed public-private telecommunications company of public significance - management challenges in staff ownership and integrity. Public Money and Management, 37(6), 389-390.

Tremblay, M.-S. (2012). Illusions of Control? The Extension of New Public Management Through Corporate Governance Regulation. Financial Accountability \& Management, 28(4), 395-416.

Ullmann, A. A. (1985). Data in Search of a Theory: A Critical Examination of the Relationships Among Social Performance, Social Disclosure, and Economic Performance of U.S. Firms. Academy of Management Review, 10(3), 540-557.

UNESCO. (1953). News agencies: their structure and operation. UNESCO.

Vakkuri, J., \& Johanson, J. E. (2018). Debate: Taming the monster - understanding hybrid organizations and governance. Public Money and Management, 38(3), 162163.

Vakkuri, J., \& Meklin, P. (2006). Ambiguity in Performance Measurement: A Theoretical Approach to Organisational Uses of Performance Measurement. Financial Accountability and Management, 22(3), 235-250.

Verhoest, K., Van Thiel, S., Bouckaert, G., \& Lægreid, P. (2012). Government Agencies. Practices and lessons from 30 Countries (K. Verhoest, S. Van Thiel, G. Bouckaert, \& P. Lægreid, Eds.).

Vining, A. R., \& Weimer, D. L. (2017). Debate: Adam Smith was skeptical of hybridsshould we be less so? Public Money and Management, 37(6), 387-388.

Waddock, S., Gilbert, D. U., \& Rasche, A. (2011). Accountability in a Global Economy: The Emergence of International Accountability Standards. Business Ethics Quarterly, 21(1), 23-44.

Wallace, G. W. (1995). Balancing Conflicting Stakeholder Requirements. The Journal for Quality and Participation, 18(2), 84-89.

Xie, E., \& Redding, K. S. (2018). State-owned enterprises in the contemporary global business scenario: introduction. International Journal of Public Sector Management, 31(2), 98-112. 
Figure 1. Hybrid vs. Private organizations theoretical effects on accountability disclosure patterns

\section{Pure Private Organizations}

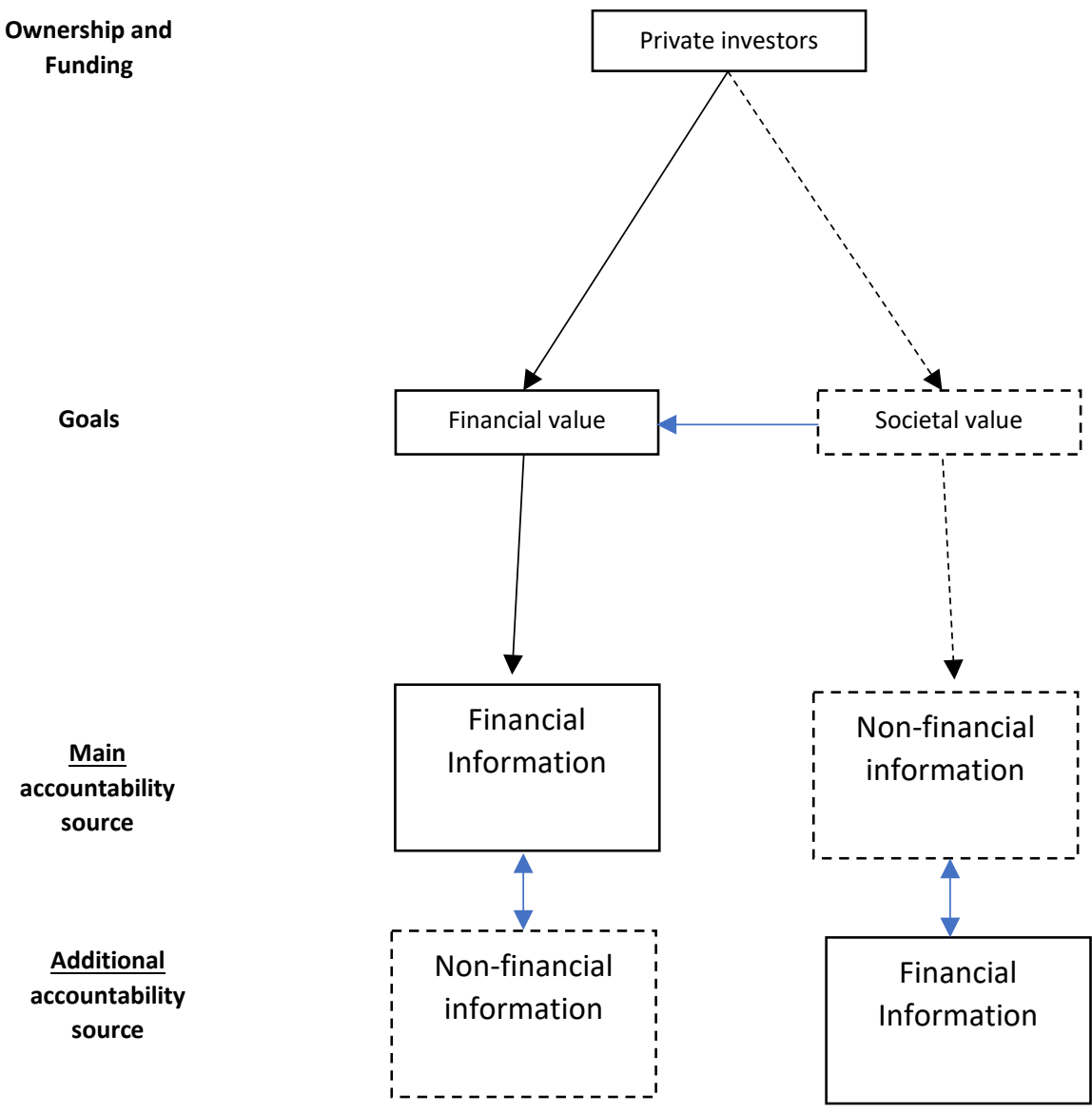

SOES as Hybrid Organizations

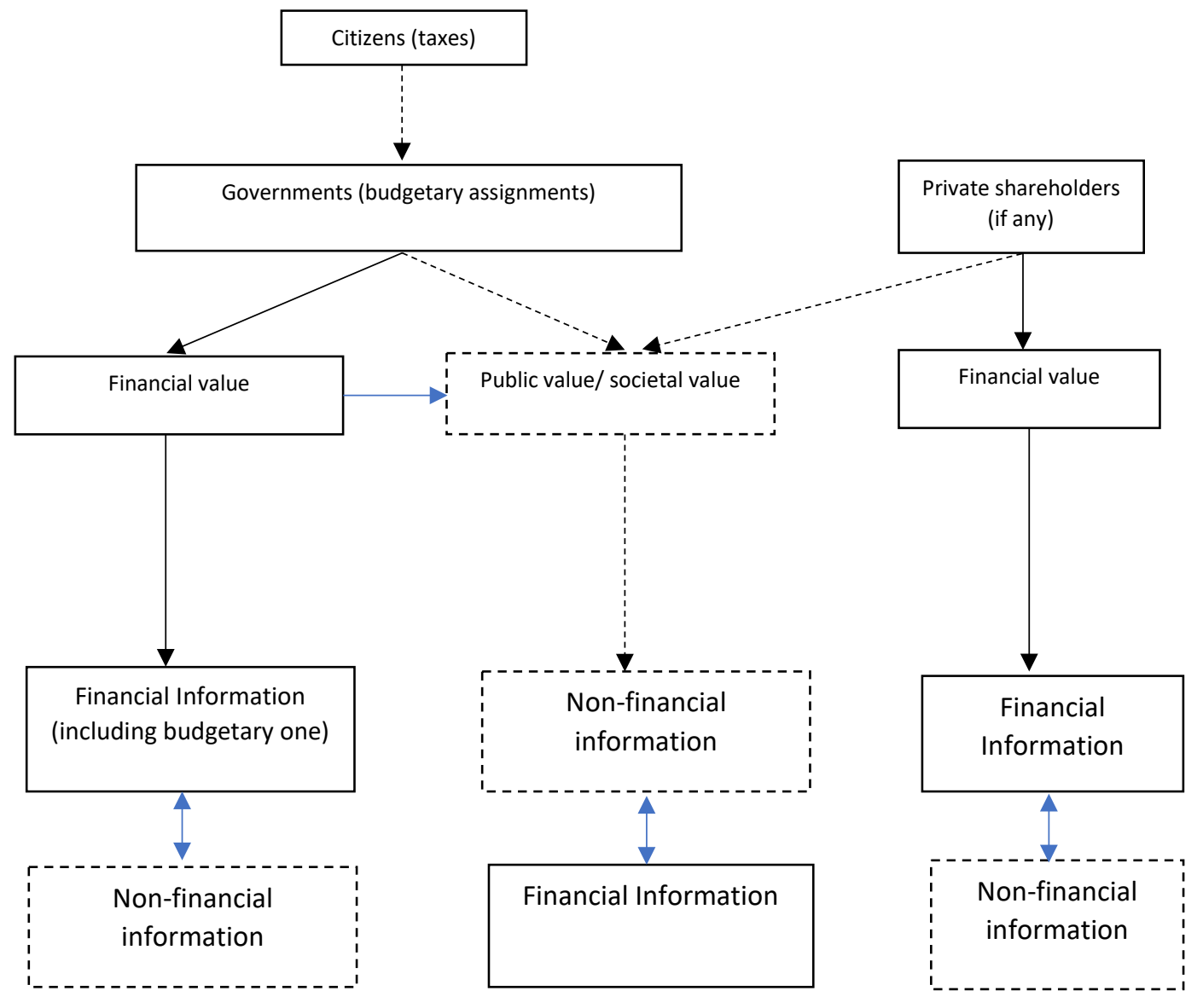


Figure 2. Hybrid vs. Private organizations theoretical effects on accountability disclosure patterns

\section{Pure Private Organizations}

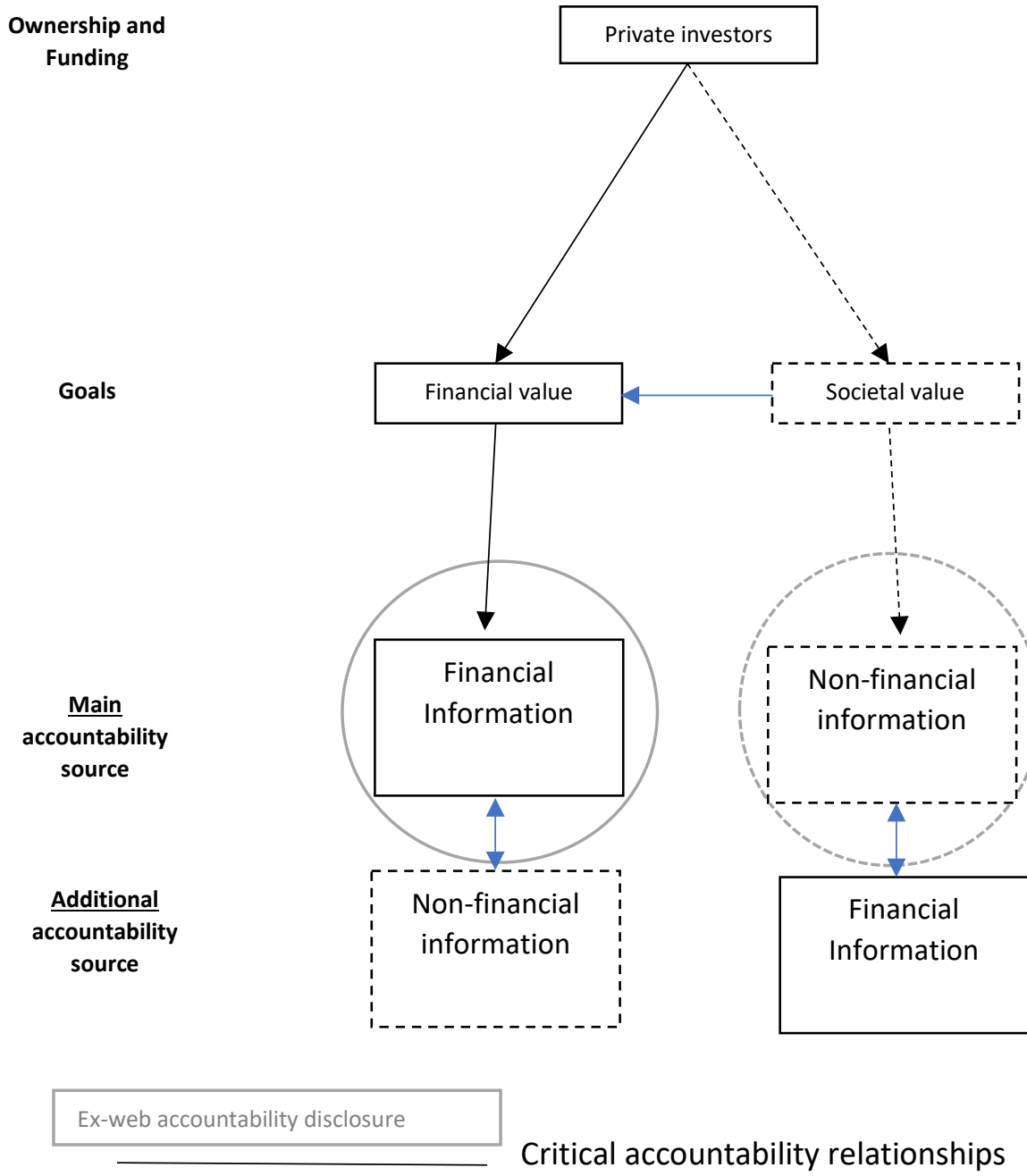

SOES as Hybrid Organizations

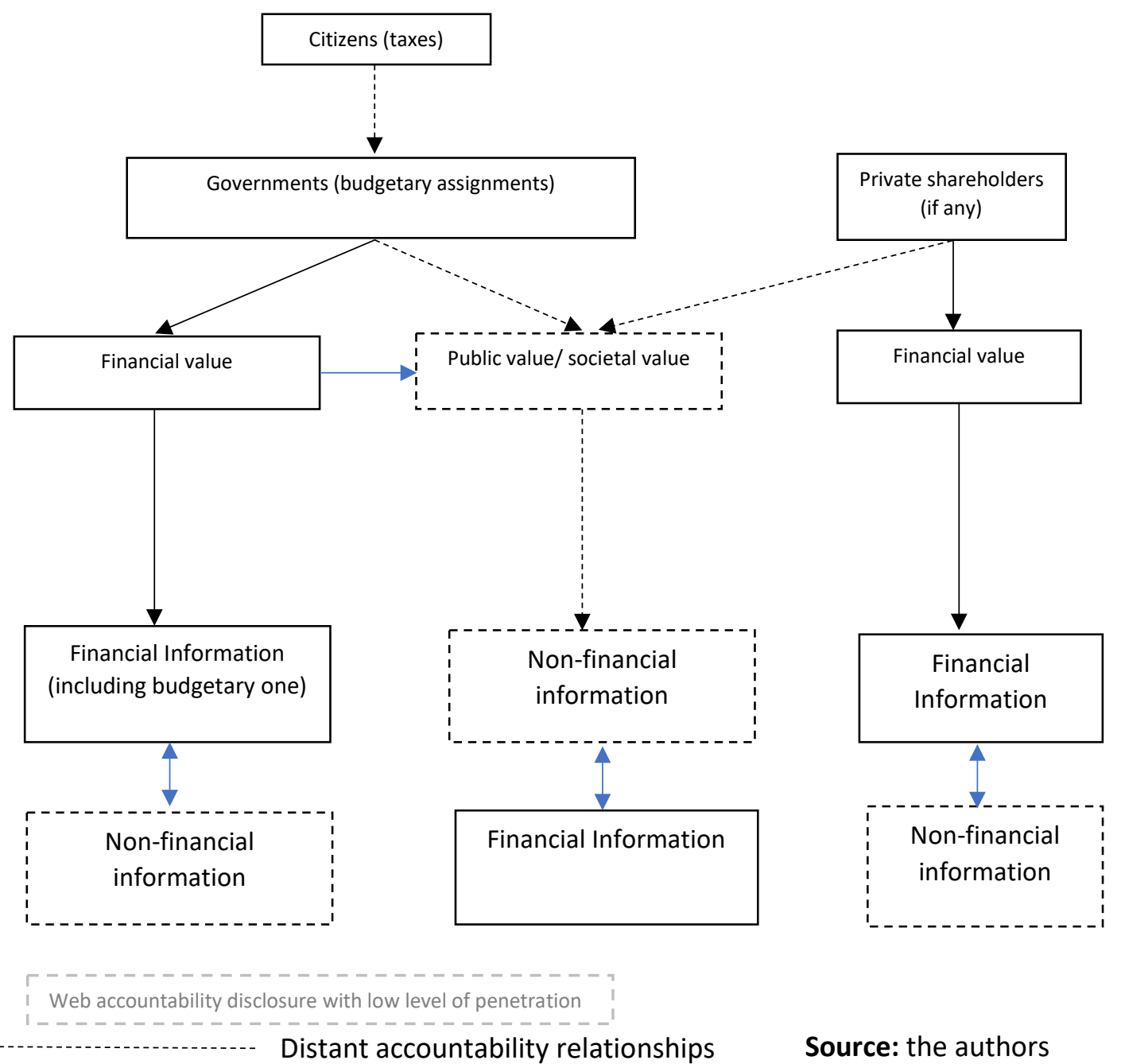


Table 1. The empirical setting: hybrid and private NAs

\begin{tabular}{|c|c|c|c|c|c|}
\hline $\begin{array}{l}\text { AGENCY } \\
\text { NAME }\end{array}$ & TYPE & COUNTRY & $\begin{array}{l}\text { AGENCY } \\
\text { NAME }\end{array}$ & TYPE & COUNTRY \\
\hline APA & Hybrid & Austria & ANSA & Private & Italy \\
\hline Belga & Private & Belgium & ELTA & Private & Lithuania \\
\hline BTA & Hybrid & Bulgaria & ANP & Private & Netherlands \\
\hline Hina & Hybrid & Croatia & NTB & Private & Norway \\
\hline CNA & Hybrid & Cyprus & PAP & Hybrid & Poland \\
\hline CTZ & Hybrid & $\begin{array}{c}\text { Czech } \\
\text { Republic }\end{array}$ & LUSA & Hybrid & Portugal \\
\hline Ritzau & Private & Denmark & Agerpres & Hybrid & Romania \\
\hline ERR & Hybrid & Estonia & TASR & Hybrid & Slovakia \\
\hline STT & Private & Finland & STA & Hybrid & Slovenia \\
\hline AFP & Private & France & EFE & Hybrid & Spain \\
\hline DPA & Private & Germany & $\mathrm{TT}$ & Private & Sweden \\
\hline AMNA & Hybrid & Greece & PA & Private & $\begin{array}{l}\text { United } \\
\text { Kingdom }\end{array}$ \\
\hline MTI & Hybrid & Hungary & & & \\
\hline
\end{tabular}

Source: the authors 
Table 2. Disclosures by sub-index of information

\begin{tabular}{|c|c|c|}
\hline \multirow{2}{*}{} & \multicolumn{2}{|c|}{ Organizational type } \\
\cline { 2 - 3 } & $\begin{array}{c}\text { Hybrid } \\
(14)\end{array}$ & $\begin{array}{c}\text { Private } \\
(11)\end{array}$ \\
\hline Financial Information & $31,63 \%$ & $18,18 \%$ \\
\hline Non-Financial Information & $22,73 \%$ & $18,18 \%$ \\
\hline Objectives, Policies and Strategies & $21,43 \%$ & $14,55 \%$ \\
\hline Corporate Governance & $23,81 \%$ & $21,21 \%$ \\
\hline Qualitative Characteristics & $55,19 \%$ & $41,32 \%$ \\
\hline Total Index & $34,96 \%$ & $26,26 \%$ \\
\hline
\end{tabular}

Source: the authors 
Table 3. Disclosure of Financial and Non-Financial Information (NFI) and Quality of the web

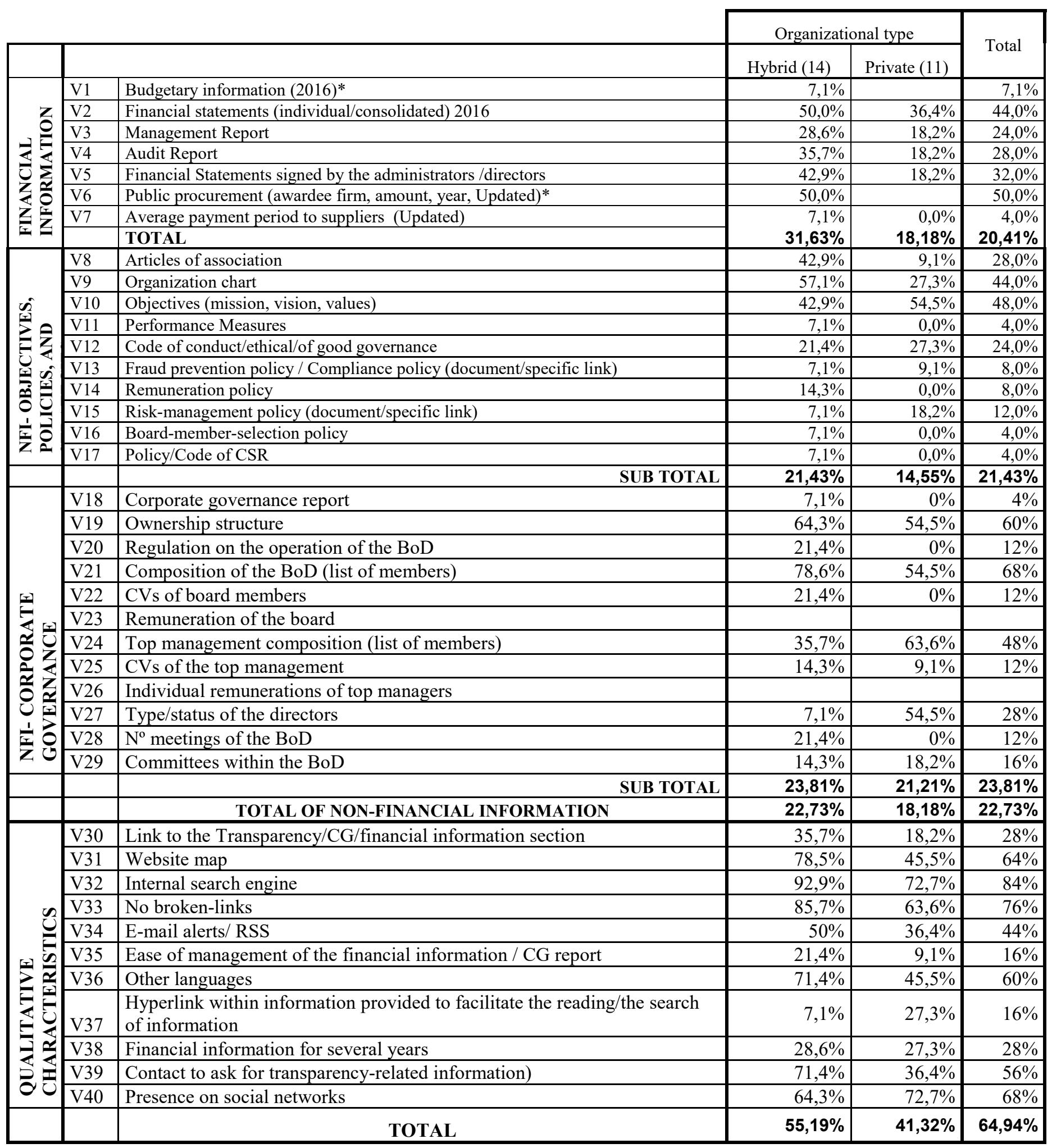

Source: the authors 